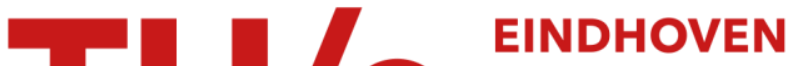 UNIVERSITY OF TECHNOLOGY
}

\section{Sergeants-and-soldiers principle in chiral columnar stacks of disc-shaped molecules with C3 symmetry}

\section{Citation for published version (APA):}

Palmans, A. R. A., Vekemans, J. A. J. M., Havinga, E. E., \& Meijer, E. W. (1997). Sergeants-and-soldiers principle in chiral columnar stacks of disc-shaped molecules with C3 symmetry. Angewandte Chemie International Edition, 36(23), 2648-2651. https://doi.org/10.1002/anie.199726481

DOI:

10.1002/anie.199726481

Document status and date:

Published: 01/01/1997

\section{Document Version:}

Publisher's PDF, also known as Version of Record (includes final page, issue and volume numbers)

\section{Please check the document version of this publication:}

- A submitted manuscript is the version of the article upon submission and before peer-review. There can be important differences between the submitted version and the official published version of record. People interested in the research are advised to contact the author for the final version of the publication, or visit the $\mathrm{DOI}$ to the publisher's website.

- The final author version and the galley proof are versions of the publication after peer review.

- The final published version features the final layout of the paper including the volume, issue and page numbers.

Link to publication

\section{General rights}

Copyright and moral rights for the publications made accessible in the public portal are retained by the authors and/or other copyright owners and it is a condition of accessing publications that users recognise and abide by the legal requirements associated with these rights.

- Users may download and print one copy of any publication from the public portal for the purpose of private study or research.

- You may not further distribute the material or use it for any profit-making activity or commercial gain

- You may freely distribute the URL identifying the publication in the public portal.

If the publication is distributed under the terms of Article 25fa of the Dutch Copyright Act, indicated by the "Taverne" license above, please follow below link for the End User Agreement:

www.tue.nl/taverne

Take down policy

If you believe that this document breaches copyright please contact us at:

openaccess@tue.nl

providing details and we will investigate your claim. 
Table 1. Comparison of interatomic distances [nm] and their assignment extracted from pair distribution functions of the $\mathrm{Ba} / \mathrm{Si} / \mathrm{O} / \mathrm{C}$ glass with those in crystalline $\mathrm{BaSi}_{2} \mathrm{O}_{5}$ and amorphous barium disilicate.

\begin{tabular}{|c|c|c|c|c|}
\hline $\begin{array}{l}\text { From AFM of } \\
\mathrm{Ba} / \mathrm{Si} / \mathrm{O} / \mathrm{C} \text { glass }\end{array}$ & $\begin{array}{l}\text { From electron } \\
\text { diffraction of } \\
\text { Ba/Si/O/C } \\
\text { glass[13] }\end{array}$ & $\begin{array}{l}\text { From neutron } \\
\text { and } X \text {-ray dif- } \\
\text { fraction of a } \\
\mathrm{BaSi}_{2} \mathrm{O}_{5} \\
\text { glass [12] }\end{array}$ & $\begin{array}{l}\text { In crystalline } \\
\mathrm{BaSi}_{2} \mathrm{O}_{5}[14]\end{array}$ & Assignment \\
\hline- & 0.165 & 0.16 & 0.16 & $\mathrm{Si}-\mathrm{O}$ \\
\hline 0.21 & - & - & - & $\mathrm{C}-\mathrm{O}(?)$ \\
\hline 0.27 & 0.28 & 0.27 & $\begin{array}{l}0.26 \\
0.27\end{array}$ & $\begin{array}{l}\mathrm{O}-\mathrm{O} \\
\mathrm{Ba}-\mathrm{O}\end{array}$ \\
\hline- & - & - & 0.30 & $\mathrm{Si}-\mathrm{Si}$ \\
\hline 0.34 & - & 0.34 & $\begin{array}{l}0.35 \\
0.35\end{array}$ & $\begin{array}{l}\mathrm{Ba}-\mathrm{Si} \\
\mathrm{Si}-\mathrm{O}\end{array}$ \\
\hline 0.41 & 0.424 & 0.415 & $\begin{array}{l}0.4 \\
0.4 \\
0.4 \\
0.41\end{array}$ & $\begin{array}{l}\mathrm{Ba}-\mathrm{O} \\
\mathrm{Ba}-\mathrm{Si} \\
\mathrm{O}-\mathrm{O} \\
\mathrm{Si}-\mathrm{O}\end{array}$ \\
\hline 0.44 & - & - & 0.45 & $\mathrm{Ba}-\mathrm{Ba}$ \\
\hline 0.48 & 0.50 & 0.494 & 0.48 & mio \\
\hline 0.57 & & 0.53 & & mro \\
\hline 0.6 & & & & mro \\
\hline 0.68 & & & & mro \\
\hline 0.77 & 0.78 & 0.78 & 0.77 & mro \\
\hline
\end{tabular}

[a] Distances above $0.45 \mathrm{~nm}$ are not assigned to a certain atomic distance pair and are attributed to medium range order effects (mro).

situated perpendicular (with respect to the surface) to a Si atom and neighboring atom.

At larger distances further peaks clearly indicate a mediumrange order in the investigated glass. However, a definite assignment has yet to be done. The appearance of the $0.77 \mathrm{~nm}$ peak both in AFM and diffraction measurements is particularly remarkable, since this is a lattice constant of crystalline barium disilicate.

Two possible problems arise with the direct imaging of fracture surfaces of amorphous solids by atomic force microscopy, if one wants to resolve the bulk structure of glasses. First, the structures on the fracture surface might undergo a relaxation and therefore not correspond exactiy to the position of the atoms in the bulk. Second, as the fracture will take place predominantly at the weaker bonds in the glass, these areas will dominate the images. However, since the relaxation in glasses with a highly developed network and low crystallization tendency will only result in displacements and not in reconstructions one can expect that the principles (repetition of structures, ring dimension, residues of translational symmetry) of medium- and long-range order will be preserved and reproduced in the image. In the case of the $\mathrm{Ba}$ / $\mathrm{Si} / \mathrm{O} / \mathrm{C}$ glass the justification for this assumption is proved by the good agreement of the AFM results with data obtained from completely independent measurements.

Atomic force microscopy is superior to all other methods of studying solids without translational symmetry in that it allows direct imaging of the atomic structure and therefore can be used to develop a reliable model of the structure of glasses. In the present case the classical controversy concerning the structure of glass between the hypothesis of Zachariasen ("network hypothesis") ${ }^{[15]}$ and that of Lebedew ("crystallite theory" ${ }^{[16]}$ can be settled. The AFM images show unambiguously that the barium silicate glass consists of a tetrahedral network.

\section{Experimental Section}

The $\mathrm{Ba} / \mathrm{Si} / \mathrm{O} / \mathrm{C}$ glass was made under argon atmosphere by melting a mixture of $\mathrm{BaCO}_{3}, \mathrm{SiO}_{2}$, and $\mathrm{SiC}$ in a high frequency furnace in a $\mathrm{BN}$ crucible placed in a carbon crucible to ensure inductive coupling. The melt was held at $1650^{\circ} \mathrm{C}$ for $30 \mathrm{~min}$ and after switching off the furnace cooled down in a strong stream of argon. The average cooling rate from maximum temperature to around $700^{\circ} \mathrm{C}$ was about $10 \mathrm{~K} \mathrm{~s}^{-1}$. The cation ratio $\mathrm{Ba}: \mathrm{Si}$ in the starting mixture was $37: 63$ with 3 atom \% carbon in form of $\mathrm{SiC}$

A fragment of this sample was clamped to the sample holder with a small vice. The images were obtained under ultrahigh vacuum after an outgassing procedure of several hours at about $400 \mathrm{~K}$ with a combined atomic force/scanning tunneling microscope (Omicron Vakuumphysik $\mathrm{GmbH}$ ). The AFM measurements were carried out in the contact mode immediately after transfer with single crystal silicon cantilevers (Nanosensors) and constant loading forces in the range $25 \mathrm{nN}-50 \mathrm{nN}[17]$.

Received: June 5, 1997 [Z10511 IE] German version: Angew. Chem. 1997, 109, 2760-2762

Keywords: amorphous materials - atomic force microscopy - glasses - structure elucidation

[1] "Glasses and Amorphous Materials", Materials Science and Technology Vol. 9 (Eds.: J. Zarzycki), VCH, Weinheim, 1991.

[2] P. G. Le Comber, J. Non-Cryst. Solids 1989, 115, 1.

[3] a) H. P. Baldus, M. Jansen, Angew. Chem. 1997, 109, 339; Angew. Chem. Int Ed. Engl. 1997, 36 , 328; b) M. Jansen, Solid State lonics 1996, in press.

[4] S. R. Elliot, Physics of Amorphous Materials, 2nd ed, Longman Scientific \& Technical, Harlow, Essex, 1990.

[5] Experimental Techniques of Glass Science (Eds. : C. J. Simmons, O. H. ElBayoumi), The American Ceramic Society, Westerville, Ohio, 1993.

[6] H. Eckert in NMR Basic Principles and Progress, Vol. 33 (Eds.: P. Diehl, E. Fluck, H. Günther, R. Kosfeld, J. Seelíg), Springer, Berlin, 1994, 127.

[7] P. Lamparter, S. Steeb in Materials Science and Technology, Vol. 1 (Eds.: Y. von Gerold), VCH, Weinheim, 1993, 217.

[8] D. R. McKenzie, Rep. Prog. Phys. 1996, 59, 1611.

(9) a) G. Binnig, C. F. Quate, C. Gerber, Phys. Rev. Lett. 1986, 56, 930; b) K. Ichikawa, J. Phys. $I$ 1995, 7 , L135; c) T. M. Schaub, D. E. Bürgler, C. M. Schmidt, H.-J. Güntherodt, J. Non-Cryst. Solids 1996, 205-207, 748

[10] F. Liebau, Structural Chemistry of Silicates, Springer, Berlin, 1985.

[11] V. Lansmann, W. Hoffbauer, N. Wartner, W. Mader, M. Jansen, Ber. BunsenGes. Phys. Chem. 1996, 100, 1635

[12] H. Hasegawa, I. Yasui, J. Non-Cryst. Solids 1987, 95-96, 201.

[13] N. Wartner, V. Lansmann, M. Jansen, W. Mader, unpublished.

[14] K. F. Hesse, F. Liebau, Z. Kristallogr. 1980, 153, 33.

[15] W. H. Zachariasen, J. Am. Chem. Soc. 1932, 54, 3841

[16] A. A. Lebedew, Arb. Staatl. Opt. Inst. Leningrad 1921, 2 No. 10, 1

[17] W. Raberg, K. Wandelt, Phys. Rev. B: Condens. Matter, submitted.

\section{Sergeants-and-Soldiers Principle in Chiral Columnar Stacks of Disc-Shaped Molecules with $C_{3}$ Symmetry**}

Anja R. A. Palmans, Jef A. J. M. Vekemans, Edsko E. Havinga, and E. W. Meijer*

Seminal studies by Green and co-workers to understand the underlying principles of chirality in stiff helical polymers such as the polyisocyanates have led to observations referred to as the "Majority Rule" and the "Sergeants-and-Soldiers Principle" [1] Poly( $n$-alkyl isocyanates) adopt an extended helical conformation in which long stretches of one helical sense, $P$ or $M$, are separated by high-energy reversals. To favor one

[*] Prof. Dr. E. W. Meijer, A. R. A. Palmans, Dr. I. A. J. M. Vekemans, Dr. E. E. Havinga

Laboratory of Organic Chemistry

Eindhoven University of Technology

PO. Box 513, NL-5600 MB Eindhoven (The Netherlands)

Fax: Int. code $+(40) 245-1036$

e-mail:tgtobm@chem.tue.nl

[**] We would like to thank Dr. H. Fischer and Dr. R. Hikmet for stimulating discussions. Unrestricted research grants from Philips Research and DSM Research are gratefully acknowledged. 
helical sense, it is only required to add a small portion of chiral units (sergeants) to the achiral units (soldiers) or to have a slight majority of $R$ over $S$ ùnits in the polymer. Recently, it was shown that these effects are operative in other polymers with stiff helical backbones. ${ }^{[2]}$ This is in sharp contrast to the behavior in small molecules where, for example, the optical rotation of a mixture of two enantiomers varies linearly with their ratio. Also in liquid crystals the induction of chirality is complex but seems to be predominantly linear or additive: ${ }^{[3]}$ the more chiral molecules added to a nematic liquid crystal, the shorter the helical pitch of the induced cholesteric phase. ${ }^{[3 b]}$ In this communication we describe our results on the stereochemical issues of the associates of disc-shaped molecules 1 in diluted alkane solutions $\left(10^{-4}-10^{-6} \mathrm{~mol} \mathrm{~L}^{-1}\right)$. The molecules are stacked in highly ordered chiral columns, with a strong, cooperative response to chiral information. This amplification in chirality furnishes the first example in which the sergeants-and-soldiers principle is operative in dynamic structures of molecular aggregates.

Extended-core disc-shaped molecules are of interest, because they show liquid-crystalline properties within a broad temperature regime, and the stability of the molecular stacks is guaranteed by many secondary interactions. ${ }^{[4]}$ We have studied in detail the synthesis and properties of achiral compounds 1 , in which the extended core is based on a concerted conformational preference owing to intramolecular $\mathrm{H}$-bonding in the three acylated 3,3'-diamino-2,2'-bipyridine moieties. ${ }^{[5]}$ Chiral analogue 1a is synthesized starting from $(S)$ citronellol, which was successively hydrogenated, brominated, coupled to methyl 3,4,5-trihydroxybenzoate and transformed by established procedures ${ }^{\mid 5 !}$ into the desired disc-shaped compound 1a. Both 1a and $1 \mathbf{b}$ show a thermotropic

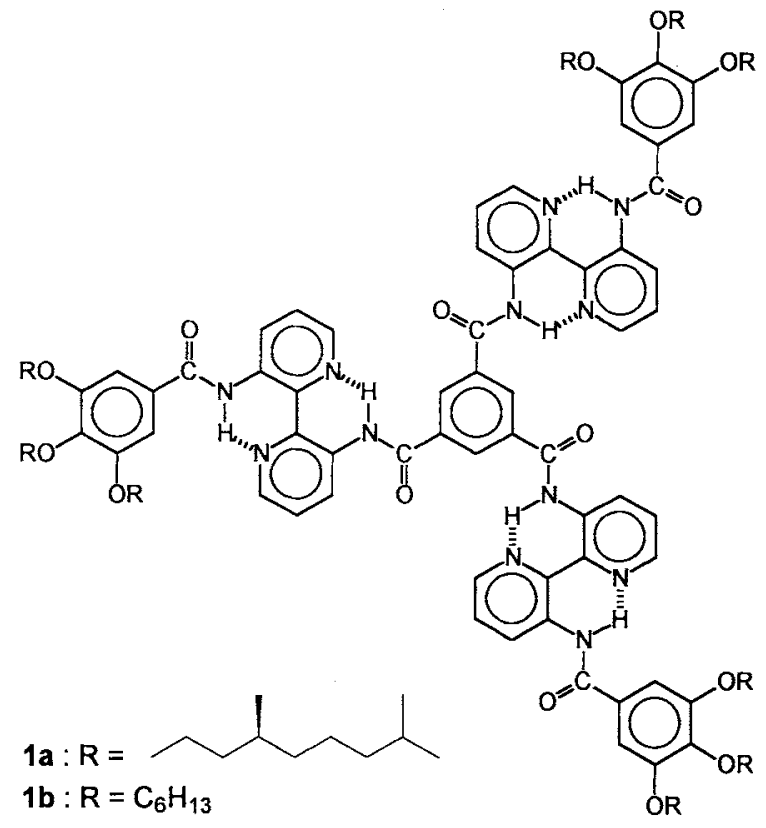

liquid crystalline $\mathrm{D}_{\text {ho }}$ phase, and X-ray diffraction suggests the presence of a helical superstructure. In concentrations greater than or equal to $7 \% \mathrm{w} / \mathrm{w}$ in apolar solvents like hexane, dodecane, and cyclohexane, molecules $\mathbf{1 b}$ are organized in a columnar phase in which the $3.5 \AA$ disc-disc distance within the columns is preserved. ${ }^{[6]}$
UV spectra of 1a,b in different solvents show distinct differences in the $\pi-\pi^{*}$ transition of the bipyridine moiety (Figure 1). In $\mathrm{CHCl}_{3} \lambda_{\max }$ amounts to $351 \mathrm{~nm}(\varepsilon=5.3 \times$

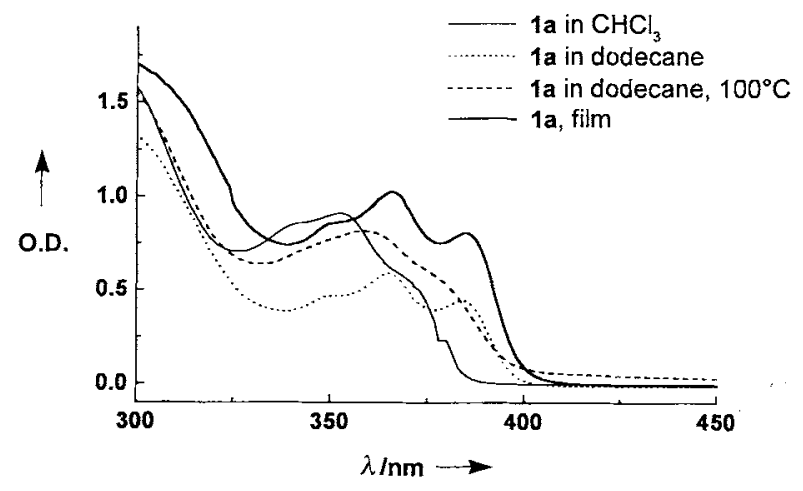

Figure 1. UV spectra of $\mathbf{1 a}$ in $\mathrm{CHCl}_{3}\left(c=1.7 \times 10^{-5} \mathrm{molL}^{-1}, l=1 \mathrm{~cm}\right)$, in dodecane $\left(c=1.8 \times 10^{-5} \mathrm{molL}^{-1}, l=1 \mathrm{~cm}\right)$, and as a neat, sheared film.

$\left.10^{4} \mathrm{~L} \mathrm{~mol}^{-1} \mathrm{~cm}^{-1}\right)$, whereas in dodecane a significant red shift of $13 \mathrm{~nm}$ is observed for $\lambda_{\max }$ to $364 \mathrm{~nm}(\varepsilon=3.2 \times$ $\left.10^{4} \mathrm{~L} \mathrm{~mol}^{-1} \mathrm{~cm}^{-1}\right)$, and a shoulder in the spectrum in $\mathrm{CHCl}_{3}$ has developed into a peak at $384 \mathrm{~nm}(\varepsilon=2.3 \times$ $\left.10^{4} \mathrm{~L} \mathrm{~mol}^{-1} \mathrm{~cm}^{-1}\right)$ in dodecane. The spectrum in dodecane resembles the UV spectrum of a sheared film of pure 1a, which is in a $D_{\text {ho }}$ phase at room temperature. Heating the dodecane solution to $100^{\circ} \mathrm{C}$ leads to a blue shift of the $\lambda_{\max }$ to $357 \mathrm{~nm}$ and the disappearance of the fine structure. These results imply that $\mathbf{1 a}$ is dissolved in $\mathrm{CHCl}_{3}$ as individual molecules (and in dodecane at $100^{\circ} \mathrm{C}$ ), while aggregation occurs in dodecane (and related alkane solvents) at room temperature in which the packing of the molecules in columns is similar to that in neat $\mathbf{1 a}$.

In $\mathrm{CHCl}_{3}$ compounds $\mathbf{1 a}, \mathbf{b}$ do not exhibit Cotton effects in the $U V / V i s$ range of the circular dichroism (CD) spectrum. In dodecane, however, 1a shows a very strong, negative Cotton effect associated with the $\pi-\pi^{*}$ absorption band of the bipyridine moiety at $\lambda=387\left(\Delta \varepsilon=-35.6 \mathrm{~L} \mathrm{~mol}^{-1} \mathrm{~cm}^{-1}\right)$ and $369 \mathrm{~nm}\left(\Delta \varepsilon=-23.6 \mathrm{~L} \mathrm{~mol}^{-1} \mathrm{~cm}^{-1}\right)$ with chiral anisotropy factors $^{[7]} g$ of $-1.5 \times 10^{-3}$ and $-7.4 \times 10^{-4}$, respectively. Heating the sample leads to a gradual decrease of the Cotton effects and a complete loss at $100^{\circ} \mathrm{C}$. Subsequent cooling to room temperature restores the original Cotton effects. Most remarkably, the UV and CD spectra of the achiral compound 1b in optically active $(R)-(-)-2,6$-dimethyloctane ${ }^{[8]}$ as solvent are almost identical to the spectra of chiral compound $1 \mathbf{a}$ in dodecane in the $\pi-\pi^{*}$ absorption band of the bipyridine moiety (Figure 2). The anisotropy factors $g$, however, are slightly lower $\left(-8.5 \times 10^{-4}\right.$ at $\lambda=386 \mathrm{~nm}$ and $-5.3 \times 10^{-4}$ at $\lambda=367 \mathrm{~nm}$ ). Again, heating of this sample leads to a decrease of the Cotton effects, showing the dynamics in chiral solvation. [9]

These results on chiral solvation indicate strong cooperative effects, suggesting a tendency of the stacks to take on a helical arrangement. We therefore attempted to apply the sergeantsand-soldiers principle to mixtures of $\mathbf{1 a}$ and $\mathbf{1 b}$ in hexane. As expected $\mathbf{1 b}$ does not show any Cotton effect in hexane. However, addition of only $2.5 \%$ of chiral $\mathbf{1 a}$ to achiral $\mathbf{1 b}$ in hexane generates a strong Cotton effect, especially in the bipyridine transition band, which was similar in magnitude as for pure $\mathbf{1 a}$ in hexane. The remarkable observation that the 


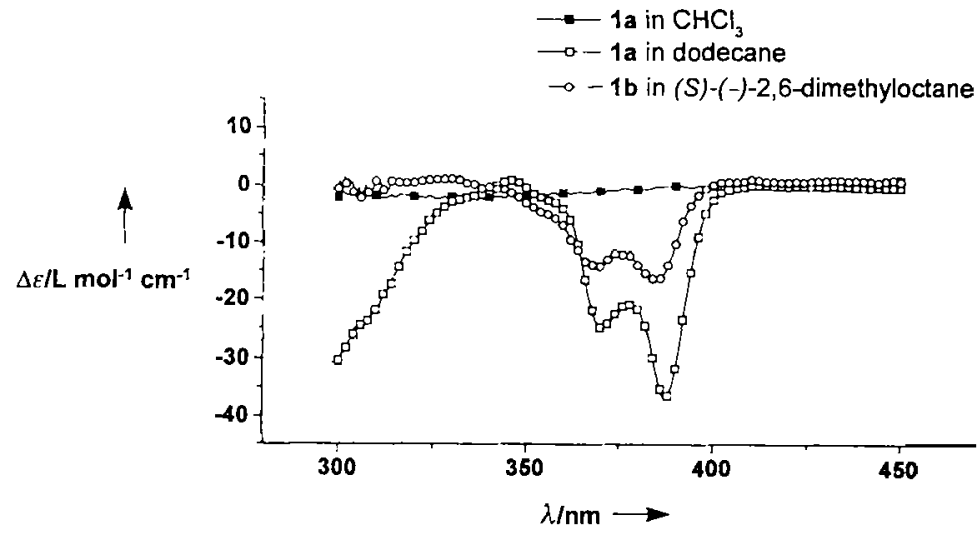

Cotton effects of the mixtures of about $10 \% \mathbf{1 a}$ and $90 \% \mathbf{1 b}$ are larger than for pure $\mathbf{1 a}$ is tentatively explained by a more effective packing between achiral molecules $\mathbf{1 b}$ than between chiral molecules 1a.

The mixing experiment was repeated with solutions of different concentrations of compounds $\mathbf{1 a}$ and $\mathbf{1 b}$ in hexane. The dependence of the $g$ values on the amount of chiral $\mathbf{1 a}$ added to a solution of achiral $\mathbf{1 b}$ is depicted in Figure 3 . The curves show the same trend, although the effect is smaller for the lowest concentration $\left(1.9 \times 10^{-6} \mathrm{~mol} \mathrm{~L}^{-1}\right)$. We also found that the Cotton effect in the bipyridine band is almost independent of the concentration of pure $\mathbf{1 a}$ in hexane within the range $10^{-6}-10^{-3} \mathrm{~mol} \mathrm{~L}-1$, with a slight deviation at the low concentration end (Figure 3, inset).

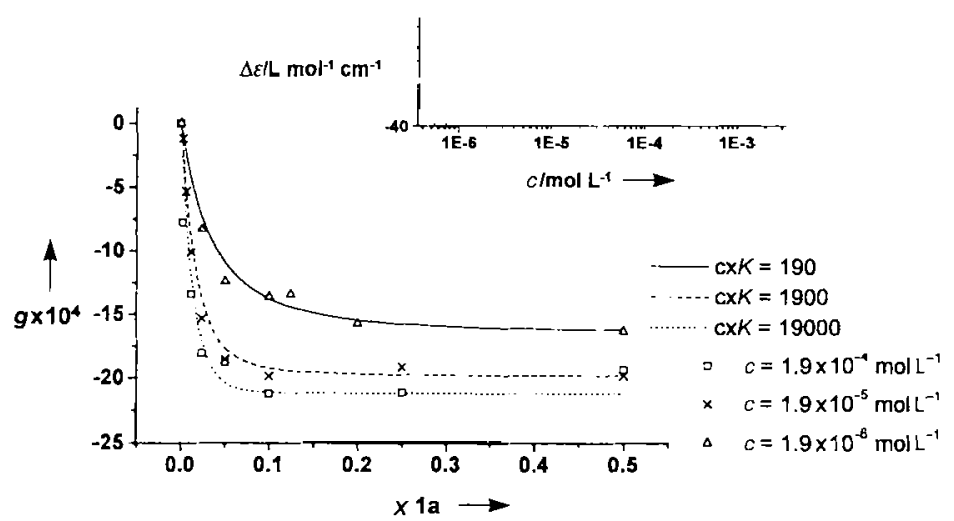

Figure 3. The anisotiopy factor $g$ as a function of the amount of 19 ( $x$ in mol fraction) added to the achiral solution of $1 b$ in hexane in $1 \mathrm{~mm}(\square) .1 \mathrm{~cm}(x)$, and $10 \mathrm{~cm}(\triangle)$ cells. The fitted lines represent the theoretically predicted development of $g$ as a function of the mol fraction of chiral compound la present in the mixture (an association constant $K$ of approximately $10^{k} \mathrm{M}$ and a cooperative length $L_{r}$ of 81 gave the optimal fit). The inset gives the helix reversals-can be varied. We assume that the contributions to the Cotton effect in the bipyridine band of a stack is proportional to the number of monomeric units in the stack, and remaining nonassociated species do not contribute to the Cotton effect. Furthermore, the association constants $K$ of chiral and achiral monomers are equal, and if a stack contains a chiral monomer, the latter will induce chirality in other molecules in the stack not further away than $s$ units. For mixed stacks in equilibrium we can then deduce an equation to fit the experimental data points with $K$ and $s$ as variables. ${ }^{[10 !}$ A fit of this model to the experimental data leads to $K=(1 \pm 0.5) \times 10^{8} \mathrm{Lmol}^{1}$ and $s-(40 \pm 2)$ which yields $L_{\mathrm{c}}=2 s+1 \approx 80$.

We propose the following hypothesis to explain the cooperative response of compound 1 on external chiral information. The $C_{3}$-symmetrical molecules of type $\mathbf{1}$ adopt a propellerlike conformation in which the bipyridine wedges are tilted with respect to the central trimesic core. ${ }^{[1]}$ In hexane molecules $\mathbf{1}$ are aggregated in columnar stacks, and the packing between subsequent molecules will be optimal when all bipyridine wedges are tilted in the same direction, which results in a preferred stable chiral conformation of each discshaped molecule..$^{12}$ This can be compared with propellers piled on top of each other. Rotating the first with respect to the second will improve the packing but will also give rise to a helix. Equal amounts of $P$ and $M$ helices are present within the stacks of achiral $\mathbf{1 b}$. The stack length is concentrationdependent and corresponds with $K \approx 10^{8} \mathrm{~L} \mathrm{~mol}^{-1}$, while the cooperative length $L_{\mathfrak{c}}$ of one helical sense between helical reversals is not concentration-dependent and has the value $L_{\mathrm{c}} \approx 80$. On the other hand, the stacks of $1 \mathrm{a}$ are assumed to have only one helical sense $P$ or $M$. The instantaneous Cotton effect in the bipyridine band upon addition of chiral 1a to a solution of achiral $\mathbf{1 b}$ points to dynamic processes and an exchange of the molecules between different columns. By introducing on average one molecule of chiral 1a per 80 molecules of $\mathbf{1 b}$ into the stacks of $\mathbf{1 b}$, the chiral component (the sergeants) will dictate the helical sense of the total stack (of soldiers) for steric reasons. That a chiral alkane solvent can also dictate the sense of helicity of a stack of achiral molecules presumably means that the first layer of solvent organizes itself along the peripheral alkoxy chains of the molecules with precision. Again, steric factors will dictate which helical sense will lead to the most favorable interactions between subsequent molecules.

In conclusion, it is shown that the sergeants-andsoldiers principle and chiral solvation are operative in dynamic, columnar stacks of molecules $\mathbf{1}$ in alkane solvents.

Received: July 10, 1997 [Z. 10675 IE] German version: Angew. Chem. 1997, 109, 2763-2765

Keywords: chirality - circular dichroism - helical structures - stacking interactions - supramolecular
The results given above are in full agreement with the strong cooperative effect of the sergeants-and-soldiers principle, but now in a dynamic system. To quantify the experimental results presented in Figure 3, we developed a theoretical model to fit these data. In this model the association constant $K$ and the cooperative length $L_{\mathrm{c}}$-which is the length of that part of the stack with only one helical sense between
[1] M. M. Green, N. C. Peterson, T. Sato. A. Teramoto, R Cook. S. Lifson, Science 1995, 268, 1860, and references herein.

(2) a) D. S. Schlitzer, B. M. Novak, Polvm. Prep. Sump. 1997, 38, 296; b) Q.S Hu, D. Vitharana. G.-Y. Liu, V. Jain, M. W. Wagaman. L. Zhang, T. Randall Lee, L. Pu, Macromolecules 1996, 29, 1082.

[3] a) T. Nakagiri, H. Kodama, K. K. Kobayashi, Phys. Rev. Lett. 1971, 27, 564; b) J. Partyka. K. Hiltrop, Liq. Cryst. 1996, 20, 611 .

[4] a) P. Herwig. L. W. Kayser, K. Müllen. H. W. Spiess Adv mater. 1996, 8, 511 ; b) B. Mohr. G. Wegner. K. Ohta. J. Chem. Soc. Chem. Commun. 1995, 995; 
c) J. Zhang, J. S. Moore, J. Am. Chem. Soc. 1994, 116, 2655; d) C Metsendorf, H. Ringsdorf, Mol. Eng. 1992, 2, 189; e) C. F. van Nostrum, S. J Picken, A.-J. Schouten, R. J. M. Nolte, J. Am. Chem. Soc. 1995, 117, 9957

[5] A. R. A. Palmans, J. A. J. M. Vekemans, H. Fischer, R. A. M. Hikmet, E. W. Meijer, Chem. Eur. J. 1997, 3, 300.

[6] Details will be published elsewhere

[7] A measure for the chirality is given by the chiral anisotropy factor $g$ (= $\Delta \varepsilon / \varepsilon)$.

[8] $(R)-(-)-2,6-D i m e t h y l o c t a n e$ was synthesized by catalytic hydrogenation of $(S)$-(+)-citronellyi bromide. ${ }^{13} \mathrm{C}$ NMR $\left(\mathrm{CDCl}_{3}\right): \delta=39.4,36.9,34.5,29.5$ $28.0,24.9,22.7,22.6,19.2,11.4$; GLC-EI-MS: $m / z 142\left(M^{+}\right), 127\left(M^{+}-\mathrm{CH}_{3}\right)$ $113\left(M^{+}-\mathrm{CH}_{2} \mathrm{CH}_{3}\right), 85,71,57,43,29 ;[\alpha]_{20}^{\mathrm{D}}=-5.5^{\circ}$ (neat).

[9] M. M. Green, N. C. Peterson, C. Khatri, J. Am. Chem. Soc. 1993, 115, 4941

[10] For mixed stacks in equilibrium we can deduce the following equation:

$$
\frac{g}{g_{0}}=\frac{\sum_{n=2}^{\infty}\left[M_{n}\right] n\left(1-q^{n}\right)+\sum_{n=s+1}^{2 s}\left[M_{n}\right]\left(n-\sum_{i=1}^{n / 2} 2 q^{s+i}\right)+\sum_{n=2 s+1}^{\infty}\left[M_{n}\right]\left(n-\sum_{i=1}^{s} 2 q^{i+s}-\sum_{i=s+1}^{n-s} q^{2 s+1}\right)}{\sum_{n=2}^{\infty}\left[M_{n}\right] n}
$$

in which $g$ is the anisotropy factor for a mixture with mol fraction $x$ of chiral $1 \mathrm{a}$ in a solution of $\mathbf{1 b}, \mathrm{g}_{0}$ is the anisotropy factor for the solution of pure 1a $[11], a=K[M]=1+[(1-\sqrt{1+4 K c}) / 2 K c]$ (M. B. Martin, Chem. Rev. 1996, $696,3043), q=1-x, t=a q, r=a \sqrt{q}$ and $s$ is the number of molecules for which chirality is controlled in one direction. Evaluation gives

$$
\frac{g}{g_{0}}=1-\frac{(2-t)\left(\frac{t}{1-t}\right)^{2}-\frac{s(1-t)+1}{(1-t)^{2}}-t^{s+1}+\frac{2\left(t^{s+1}-t^{2 s+1}\right)}{(1-a)(1-q)}+\frac{t^{2 s+1}}{(1-a)^{2}}-\frac{2(q r)^{s+1}\left(1-r^{s}\right)}{(1-q)(1-r)}}{(2-a)\left(\frac{a}{1-a}\right)^{2}}
$$

[11] For the constant $g_{0}$, the $g$ value of the $10 / 90$ mixture $1 \mathrm{a} / 1 \mathrm{~b}$ was used in the fit to compensate for packing effects.

[12] In (-)- and (+)-3,3'-di(camphanoylamino)-2,2'-bipyridine in $\mathrm{MeOH}$ and $\mathrm{CHCl}_{3}$, weak Cotton effects are found in the bipyridine band, which are attributed to a small deviation from coplanarity of the bipyridine system.

[13] This packing of the molecules in columns could be stabilized by intermo lecular H-bonding. See a) Y. Yasuda, E. Iishu, H. Inada, Y. Shirota, Chem Lett. 1996, 575; b) Y. Yasuda, Y. Takebe, M. Fukumoto, H. Inada, Y. Shirota, Adv. Mater. 1996, 8, 740 .

\section{$\mathbf{B a}_{2} \mathbf{N d}_{7} \mathbf{S i}_{11} \mathbf{N}_{23}-A$ Nitridosilicate with a Zeolite-Analogous Si-N Structure**}

\section{Hubert Huppertz and Wolfgang Schnick*}

In the past few decades zeolites and aluminosilicates have found important technological applications as microporous solids. ${ }^{[1]}$ For the specific modification of their catalytic properties the tetrahedral centers aluminum and silicon were substituted by a large number of electropositive elements. ${ }^{[1,2]}$ Recently, the replacement of the bridging atoms $O$ by different atoms or building units in the network structures was successful. ${ }^{[3]}$ For example, $\mathrm{Zn}_{6}\left[\mathrm{P}_{12} \mathrm{~N}_{24}\right] \mathrm{Cl}_{2}$ with a sodaliteanalogous structure of corner-sharing $\mathrm{PN}_{4}$ tetrahedra was synthesized in our group. ${ }^{[4]}$ Host - guest behavior by reversible encapsulation of molecular hydrogen was established for the analogous halogen-free nitridosodalite $\mathrm{Zn}_{6}\left[\mathrm{P}_{12} \mathrm{~N}_{24}\right]^{[5]}$

With regard to the material properties and the high stability of nitridosilicates, it seemed challenging to build up zeoliteanalogous microporous network structures from $\mathrm{SiN}_{4}$ tetrahedra. Typical for nearly all oxidic zeolites is a molar ratio of tetrahedral centers $(T)$ to bridging atoms $(X)$ of $T: X=1: 2$

[*] Prof. Dr. W. Schnick, Dipl.-Chem. H. Huppertz

Laboratorium für Anorganische Chemie der Universität

D-95440 Bayreuth (Germany)

Fax: Int. code + (921) 55-2788

e-mail: wolfgang.schnick@uni-bayreuth.de

[**] This work was supported by the Fonds der Chemischen Industrie and the Deutsche Forschungsgemeinschaft (Projekt "Nitridozeolithe" SCHN 377 I 6-1 and in the Gottfried-Wilhelm-Leibniz program).

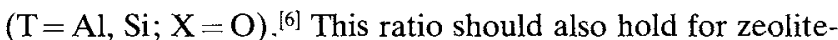
analogous nitridosilicates. All nitridosilicates obtained so far by high-temperature synthesis possess $\mathrm{Si}-\mathrm{N}$ substructures in the range $0.5 \leq \mathrm{T}: \mathrm{X} \leq 0.75$ having no open channels or large cavities. ${ }^{[7]}$

The synthesis of $\mathrm{Ba}_{2} \mathrm{Nd}_{7} \mathrm{Si}_{11} \mathrm{~N}_{23}$ produced the first nitridosilicate with a zeolite-analogous $\mathrm{Si}-\mathrm{N}$ network structure. The new nitridosilicate was synthesized in a high-frequency furnace ${ }^{[8]}$ by reaction of stoichiometric amounts ${ }^{[9]}$ of barium and neodymium with silicon diimide ${ }^{[10]}$ under nitrogen atmosphere [Eq. (a)]. By this procedure $\mathrm{Ba}_{2} \mathrm{Nd}_{7} \mathrm{Si}_{11} \mathrm{~N}_{23}$ is formed as a coarse crystalline, dark blue solid. ${ }^{[11]}$ Like all other nitridosilicates synthesized in our group, $\mathrm{Ba}_{2} \mathrm{Nd}_{7} \mathrm{Si}_{11} \mathrm{~N}_{23}$ is stable up to $1600^{\circ} \mathrm{C}$ and insensitive to hydrolysis.

$$
2 \mathrm{Ba}+7 \mathrm{Nd}+11 \mathrm{Si}(\mathrm{NH})_{2}+1 / 2 \mathrm{~N}_{2} \frac{900-1650^{\circ} \mathrm{C}, 40 \mathrm{~h}}{\mathrm{HF} \text { furnace }} \underset{\mathrm{Ba}_{2} \mathrm{Nd}_{7} \mathrm{Si}_{11} \mathrm{~N}_{23}+11 \mathrm{H}_{2}}{ }
$$

The X-ray structure analysis ${ }^{[12]}$ on single crystals of $\mathrm{Ba}_{2} \mathrm{Nd}_{7} \mathrm{Si}_{11} \mathrm{~N}_{23}$ shows a three-dimensional network structure of corner-sharing $\mathrm{SiN}_{4}$ tetrahedra according to ${ }_{\infty}^{3}\left[\left(\mathrm{Si}_{11}^{[4]} \mathrm{N}_{2}^{[1]} \mathrm{N}_{21}^{[2]}\right)^{25-}\right]$. With a molar ratio of $\mathrm{Si}: \mathrm{N}=11: 23$, the degree of condensation is smaller than in most of the oxidic zeolites ( $\mathrm{Al} / \mathrm{Si}: \mathrm{O}=1: 2)^{[13]}$ Accordingly besides bridging atoms $\mathrm{N}^{[2]}$, terminal atoms are connected to $\mathrm{Si}$ $\left(\mathrm{N}^{[1]}\right)$. (The superscript in square brackets in $\mathrm{N}^{[x]}$ defines the number of $\mathrm{Si}$ atoms covalently bound to $\mathrm{N}$, and vice versa for $\left.\mathrm{Si}^{\left[{ }^{[x}\right]}\right)$. The ratio of $\mathrm{Q}^{4}$ and $\mathrm{Q}^{2}$ tetrahedra in the $\mathrm{Si}-\mathbf{N}$ network structure is 10:1. Thus $\mathrm{Ba}_{2} \mathrm{Nd}_{7} \mathrm{Si}_{11} \mathrm{~N}_{23}$ shows the lowest degree of condensation amongst the $\mathrm{Si}-\mathrm{N}$ network structures obtained so far. The network of corner-sharing $\mathrm{SiN}_{4}$ tetrahedra in $\mathrm{Ba}_{2} \mathrm{Nd}_{7} \mathrm{Si}_{11} \mathrm{~N}_{23}$ can be characterized by the specific distribution of $\mathrm{Si}_{n} \mathrm{~N}_{n}$ ring sizes. ${ }^{[14]}$ In $\mathrm{Ba}_{2} \mathrm{Nd}_{7} \mathrm{Si}_{11} \mathrm{~N}_{23}$ all ring sizes appear with the exception of $n=2$ and 5 .

Characteristic for the structure of $\mathrm{Ba}_{2} \mathrm{Nd}_{7} \mathrm{Si}_{11} \mathrm{~N}_{23}$ (Figure 1) are channels along [001]. The $\mathrm{Ba}^{2+}$ ions are centered in the $\mathrm{Si}_{8} \mathrm{~N}_{8}$ ring channels and in the $\mathrm{Si}_{6} \mathrm{~N}_{6}$ ring channels along [100]. The $\mathrm{Nd}^{3+}$ ions are positioned in the smaller voids. The metal ions are coordinated by seven and eight nitrogen atoms of the $\mathrm{Si}-\mathrm{N}$ network $\left(\mathrm{Ba}^{2+}-\mathrm{N} ; 273(1)-316(2) \mathrm{pm} ; \mathrm{Nd}^{3+}-\mathrm{N}\right.$ : $229(2)-312(1) \mathrm{pm})$. The $\mathrm{Ba}^{2+}$ ions in the wide $\mathrm{Si}_{8} \mathrm{~N}_{8}$ ring channels (Figure 2) have a markedly higher coordination number of 16 and corresponding longer distances to the nitrogen atoms $\left(\mathrm{Ba}^{2+}-\mathrm{N}: 337(1)-441(2) \mathrm{pm}\right)$.

The bond distances $\mathrm{Si}-\mathrm{N}^{[2]}$ in the network structure $(167(1)-175.5(5) \mathrm{pm})$ are typical for simple bridging $\mathrm{N}^{[2]}$ atoms in nitridosilicates. ${ }^{[7]}$ The distances $\mathrm{Si}-\mathrm{N}^{[1]}$ (175.4(12) pm) correspond to the values of terminal $\mathrm{N}$ atoms in $\mathrm{Ba}_{5} \mathrm{Si}_{2} \mathrm{~N}_{6}(174-176 \mathrm{pm})$. $^{[15]}$

A measure for the microporousity of a zeolite-analogous structure is the framework density (FD), which indicates the number of tetrahedral centers $(T)$ in a volume of $1000 \AA^{3}$. With a FD of $18.5, \mathrm{Ba}_{2} \mathrm{Nd}_{7} \mathrm{Si}_{11} \mathrm{~N}_{23}$ is similar to typical zeolites (framework densities of some zeolites in $\mathrm{T} /\left(1000 \AA^{3}\right)$ : 17.5 $\left(\mathrm{AlPO}_{4}-5\right), 17.9$ (ZSM-5), 19.3 (Nonasil)). ${ }^{[6]}$

The successful synthesis of $\mathrm{Ba}_{2} \mathrm{Nd}_{7} \mathrm{Si}_{11} \mathrm{~N}_{23}$ is the first proof that not only highly condensed $\mathrm{Si}-\mathrm{N}$ network structures but also open, zeolite-like networks of corner-sharing $\mathrm{SiN}_{4}$ tetrahedra can be realized. In contrast to conventional zeolites, which are synthesized by solvothermal procedures using templates, the nitridosilicates are only accessible by high-temperature synthesis. The next aim of our efforts will be the exchange of the bulky metal ions for hydrogen atoms 